\title{
Forecasting the impact of buildings with multi- storey underground parts on the displacement of subsoil using modern numerical tools
}

https://doi.org/10.2478/sgem-2021-0034

received September 7, 2021; accepted October 31, 2021.

\begin{abstract}
The paper will analyse and review the experience to date in determining the impact range of implementation of deeply founded structures on the displacement of the subsoil in the vicinity.

With the background of these experiences, primarily empirical, the present possibilities of using numerical modelling to forecast the displacements of the terrain surface in various stages of works, that is, execution of deep excavation support systems, excavation-deepening phases with successive adding of struts, construction of underground levels and erection of the above-ground part of the building, will be presented.

Based on the results of own research, conclusions on the use of 3D numerical models in spatial shaping and designing the structure of underground parts of new buildings erected in dense urban development will be presented. The characterised 3D numerical models were verified, taking into account the actual results of geodetic measurements of the completed buildings.
\end{abstract}

Determining the range and forecasting the displacements of the subsoil are necessary for the design and implementation of investments due to the need to ensure the safety of erection and use of a new building and the buildings located within the area of influence.

Keywords: influence on neighbouring constructions; soil displacement; 3D numerical modelling; deep building foundations; buildings with multi-storey undergrounds.

*Corresponding author: Pawet Przybysz, Warsaw University of Technology, Faculty of Architecture, Poland,

E-mail: pawel.przybysz@pw.edu.pl

Hanna Michalak, Warsaw University of Technology, Faculty of Architecture, Poland

\section{Introduction}

Owing to the decreasing resources of construction grounds in cities and the high prices of such areas, a need arises for rational use of the building plot plan. Usually, it is entirely intended for development, whereas the buildings are often placed at the meeting point of existing neighbouring building development. More and more often, additional functions of facilities, for example, garages, warehouses, technical back-up rooms, etc., being auxiliary in relation to the standard purposes provided for in the building's above-ground levels, are introduced in multi-storey underground levels. For these reasons, new buildings erected in cities are equipped with numerous underground levels.

The erection of a low-slung building within the immediate vicinity of existing building structures impacts the displacement of the subsoil. It thus influences the technical condition of the neighbouring building development.

For these reasons, when preparing this type of investment, it is necessary to account for the existing conditions, including technical and legal conditions. It is also vital that the investment is preceded by determination of the scope of impact of the designed building on the subsoil displacement. The building implementation should be designed and prepared in such a way as to ensure that the requirements of the ultimate load-bearing capacity and serviceability limit states are met for the planned building, as well as for the existing building structures located within its impact zone.

Displacement of the subsoil depends on a variety of factors, including, primarily, change in the state of stress resulting from the relief and load on the subsoil, the subsoil type, its strength and deformation parameters, deformation of the foundation excavation casing, possible lowering of the groundwater mirror, technology applied to dig the foundation excavation casing and its support at height, surface area and shape of the planned excavation 
and its depth. The above-mentioned factors also affect the scope of impact of the new investment on the subsoil displacement. During the construction of a low-slung structure, this scope of impact changes depending on the state of stress, that is, the stage of the construction works.

Due to the complexity of the issues, a new investment's scope of impact had previously been empirically determined by numerous researchers for specific cases of subsoils or a particular technology of excavation applied. Usually, the scope of impact was only defined for the excavation phase of the trench, depending on its depth (h). For example:

- in the case of the subsoil formed of the London loam and glacial tills, Clough and O'Rourke [1] determined the impact range of the foundation excavation on the deformation of the land surface as being $2.0-4.0 \mathrm{~h} \mathrm{(h}$ excavation depth);

- for the same type of subsoil formed of the London loam and glacial tills, Symons and Carder [2] estimated the impact range of the foundation excavation as 2.02.5h;

- in the case of non-cohesive soils (fine sand, medium sands and gravel), Breymann [3] assessed the impact range of the foundation excavation at 1.5-2.0h;

- Simpson [4] defined the impact range on strong cohesive soils as being, on average, 2.0-3.0h and, in extreme cases, as 5.0h;

- Smoltczyk [5] estimated the impact range of the foundation excavation (disappearance of vertical displacements) on the subsoil to be approximately 0.6-2.0h;

- Michalak, Pęski, Pyrak and Szulborski [6] found that the greatest range of vertical displacements of the ground surface occurs in the zone of $0.5-0.75 \mathrm{~h}$ width from the trench excavation edge and disappears within $2.0 \mathrm{~h}$, whereas in the case that the groundwater mirror is lowered, the impact range increases and amounts to 3.0-4.0h;

- Wysokiński and Kotlicki [7] determined the range of direct impact area of the foundation excavation. (Within the immediate vicinity of the foundation excavation, in exceptional cases, ground displacements are likely to threaten the bearing capacity of the building structure.) The researchers determined the impact area range depending on the type of soil that makes up the ground. According to them, the impact area range equals $0.5 \mathrm{~h}$ in sands, $0.75 \mathrm{~h}$ in loams and $1.0 \mathrm{~h}$ in clays. However, the scope of the secondary impact area (in which the ground displacements may cause damage to the building, but do not threaten the load-bearing capacity of the structure) was determined at the following values: 2.0h in sands, $2.5 \mathrm{~h}$ in loams and 3.0-4.0h in clays. It was also found that this zone range decreases by about $20 \%$ if the groundwater mirror is not lowered.

- In her work [8], Michalak explored the impact zones of low-slung structure construction on subsoil displacement within their vicinity. She estimated these displacements in subsequent implementation phases, that is, the underground part of the construction phase (phase II) and the phase related to constructing the above-ground part of the structure with the application of service load (phase III). Based on research concerning objects $[8,9]$ with underground parts protected with casings made up of a slurry wall supported at height with straining beams or implemented using the Milan (top-slab) method, the impact zones of the new building in subsequent phases were determined.

Four zones, that is, $\mathrm{S}_{0.75}, \mathrm{~S}_{0.50}, \mathrm{~S}_{0.25}$ and $\mathrm{S}_{0}$, were determined, whose range depended on the absolute values of vertical displacements at the edge of the foundation excavation $\mathrm{v}_{0}$, which did not exceed $0.75 \mathrm{v}_{0}, 0.50 \mathrm{v}_{0}, 0.25 \mathrm{v}_{0}$ and 0 (disappearance of displacement), respectively. The range of impact of the foundation excavation was determined concerning buildings in which case the subsoil was shaped by inhomogeneous soils with sands or loams underlying the level of the bottom slab. It was determined that the extent of the $\mathrm{S}_{0.75}, \mathrm{~S}_{0.50}$ and $\mathrm{S}_{0.25}$ zones in phases II and III was independent of soil conditions, while the extent of the $\mathrm{S}_{0}$ zone depended on the type of soil underlying the bottom slab level. In phase II, the ranges of these zones equalled $\mathrm{S}_{0.75}=0.5 \mathrm{~h}, \mathrm{~S}_{0.50}=0.7 \mathrm{~h}, \mathrm{~S}_{0.25}=1.1 \mathrm{~h}$ and $\mathrm{S}_{0}=1.7 \mathrm{~h}$ (in the case of sands underlying the bottom slab) or $5.4 \mathrm{~h}$ (for clays). In phase III, the ranges of these zones stood at $S_{0.75}=0.5 \mathrm{~h}$, $\mathrm{S}_{0.50}=0.8 \mathrm{~h}, \mathrm{~S}_{0.25}=1.3 \mathrm{~h}$ and $\mathrm{S}_{0}=2.8 \mathrm{~h}$ (in the case of sands underlying the bottom slab) or $5.4 \mathrm{~h}$ (in the case of clay).

Depending on the construction work phase, variability in the range of impact exerted by the construction of a low-slung facility on the displacement of the land surface within its vicinity was observed. Given this aspect, the present article discusses the scope of such changes based on a case study of a facility implemented in Warsaw. In the implementation mentioned above, a 3D numerical model of the facility was developed using Zsoil software [10]. The model was then calibrated based on the results obtained from geodetic measurement of the vertical displacements of the stabilised geodesic benchmarks on the existing neighbouring buildings, which were taken during the implementation of the investment (detailed information is given in [11]). 
The technology applied for foundation excavation works for low-slung structures and its impact on the subsoil displacement and determination of the soil parameters for the design of such buildings have been the subject of analyses presented in various scientific publications, including [12-29].

\section{Materials and Methods}

\subsection{General characteristics of the studied implementation}

The present research covers a housing complex in Warsaw [30-34], which consists of three buildings: A, B and C (Fig. 1), located upon a common underground part. The underground part was built on an irregular plan, whose area totalled about 5,000 $\mathrm{m}^{2}$ (Fig. 2). The excavation for the underground part measured $4.7 \mathrm{~m}$ below the ground level. The casing of the excavation was made of slurry walls, $60 \mathrm{~cm}$ thick, immersed in cohesive soils to cut off groundwater inflow from 8.0 to $10.0 \mathrm{~m}$ below the ground to the inside of the foundation excavation. The stability of the slurry wall during the excavation works was ensured by supporting it at height with straining beams made of $\varnothing 711 / 12.5, \varnothing 502 / 12.5$ steel pipes and HEB 300 beams [30]. A non-dilated foundation slab with slopes in the direction of linear drainage was designed and installed in the form of the so-called 'white tub' waterproofing construction. The complex of A, B and C buildings is mainly located on a layer of medium-compacted sands, about $2.0 \mathrm{~m}$ below the maximum groundwater mirror. Existing building development is situated within the vicinity of the investment, including a baroque church with monastery buildings, a classicist building from 1850, a historic, modernist five-storey tenement house erected in 1935, a multi-family residential building with 17 above-ground levels, as well as five residential buildings of various sizes with several above-ground levels ranging from five to nine storeys.

\subsection{Soil and water conditions}

The building complex is located approximately $150 \mathrm{~m}$ away from the Vistula riverbed. While conducting geotechnical investigations, it was established that the initial level of groundwater is observable at a depth of 3.5-5.5 m below sea level.

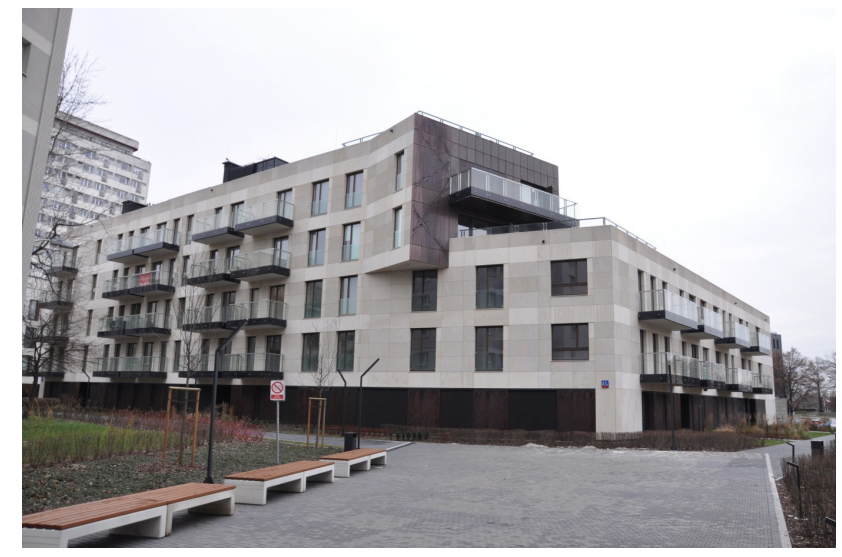

Figure 1: General view of the development (building B).

The following geotechnical layers constitute the subsoil in the investment area: embankments of rubble with an admixture of sand and clay, the thickness of which ranges from 1.0 to $3.8 \mathrm{~m}$ (layer I); a discontinuous layer of clay and sandy clay with an admixture of organic parts (layer IIa, IIb) in a hard-malleable state and locally in a malleable form, with a thickness of up to $2.0 \mathrm{~m}$; medium and coarse sands in a moderately compacted form, with a thickness of 2.5-5.5 m, constituting a lower lawyer (layer IIIa, IIIb); locally fine sands and dusty sands (layer IV) and moderately compacted, locally found dusty formations (layer V) in a semi-compact state. At a depth of 5.0-8.0 m below sea level, Pliocene clays (layer VIa, VIb) in a hard-malleable and semi-compact form are observed [34].

The building assembly is mostly erected upon a layer of medium-compacted sands (layer III), about $2.0 \mathrm{~m}$ below the maximum level of the groundwater mirror.

The geotechnical parameters of soils based on the design documentation are provided in Table 1, whereas the geotechnical cross section is shown in Fig. 3.

\subsection{Numerical model}

A spatial numerical model to map an area of $240 \times 150 \mathrm{~m}$, including new A, B, C and adjacent buildings, is illustrated in Fig. 4. The model was created in the ZSoil 2016 program by ZACE Services Ltd., while geotechnical parameters were adopted from the technical documentation of the facility. Parameters such as the construction work phases resulting from the actual stages of the investment implementation, the load values of buildings and the manner and place of their application were determined based on an analysis of the design documentation. 


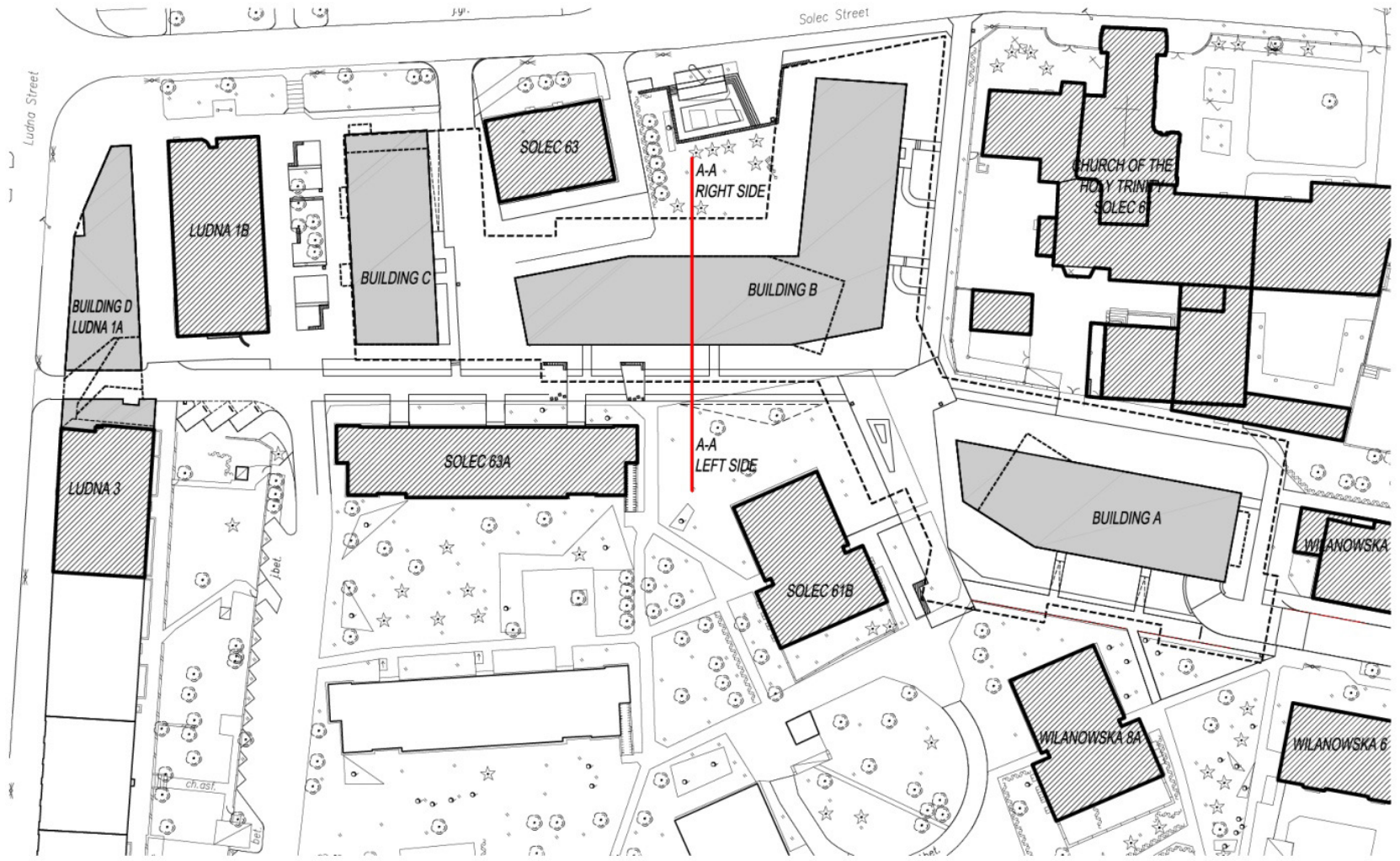

Figure 2: Site plan of the investment and existing neighbouring buildings with determination of the A-A test section placement. The outline of the underground part of the new housing complex is marked by a dotted line (own study based on [32], [11]).

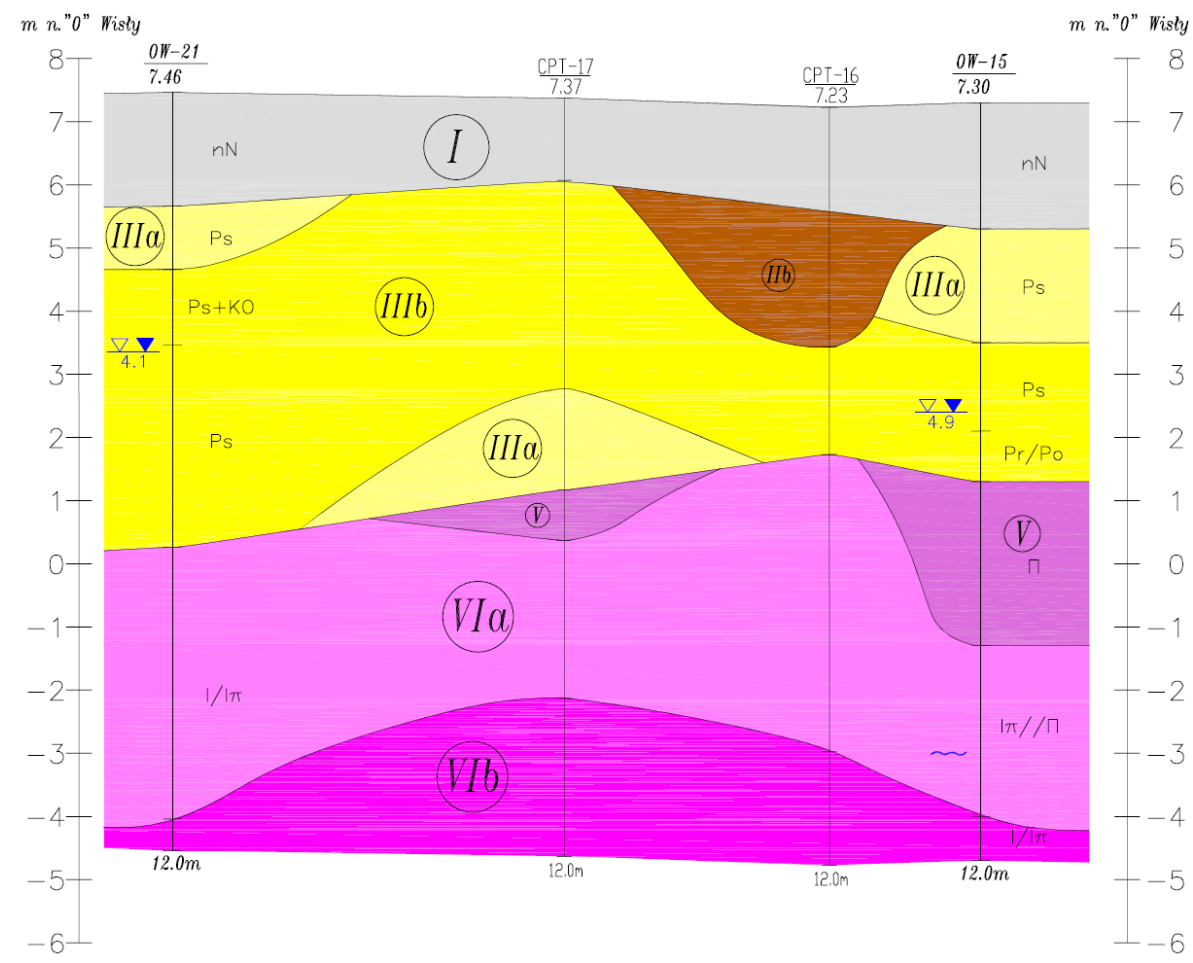

Figure 3: Geotechnical cross section [34] 
Table 1: Subsoil parameters adopted in the model of the subsoil on the basis of the documentation [34].

\begin{tabular}{|c|c|c|c|c|c|c|c|c|c|}
\hline $\begin{array}{l}\text { Layer } \\
\text { No }\end{array}$ & $\begin{array}{l}\text { Compaction } \\
\text { index }\end{array}$ & $\begin{array}{l}\text { Plasticity } \\
\text { index }\end{array}$ & $\begin{array}{l}\text { Weight/ } \\
\text { unit } \\
\text { volume }\end{array}$ & $\begin{array}{l}\text { Friction } \\
\text { angle }\end{array}$ & Cohesion & $\begin{array}{l}\text { Dilatancy } \\
\text { angle }\end{array}$ & $\begin{array}{l}\text { Poisson } \\
\text { ratio }\end{array}$ & $\begin{array}{l}\text { Compression } \\
\text { modulus based on } \\
\text { CPT probing }\end{array}$ & $\begin{array}{l}\text { Modulus of } \\
\text { elasticity based } \\
\text { on CPT probing }\end{array}$ \\
\hline & $I_{D}$ & $I_{L}$ & $\begin{array}{l}\mathrm{y} \\
\left(\mathrm{kN} / \mathrm{m}^{3}\right)\end{array}$ & $\begin{array}{l}\varphi \\
\left({ }^{\circ}\right)\end{array}$ & $\begin{array}{l}\mathrm{c} \\
(\mathrm{kPa})\end{array}$ & $\begin{array}{l}\psi \\
\left(^{\circ}\right)\end{array}$ & $v$ & $\begin{array}{l}\mathrm{M} \\
(\mathrm{kPa})\end{array}$ & $\begin{array}{l}\mathrm{E} \\
(\mathrm{kPa})\end{array}$ \\
\hline I & - & - & $16-18$ & 24 & - & - & 0.25 & - & 15,000 \\
\hline Ila & - & 0.3 & 20 & - & - & - & 0.32 & 5,000 & 3,500 \\
\hline IIb & - & $0.1-0.2$ & 21.5 & 15 & 17 & - & 0.32 & 15,000 & 10,500 \\
\hline IIla & 0.4 & - & 18.5 & 32 & - & 2 & 0.25 & 75,000 & 62,500 \\
\hline IIIb & 0.6 & - & 19.0 & 34 & - & 4 & 0.25 & 110,000 & 91,700 \\
\hline IV & $0.4-0.6$ & - & 17.5 & 31 & - & 1 & 0.30 & $90,000-120,000$ & 78,000 \\
\hline V & - & 0.0 & 21 & 22 & 40 & - & 0.29 & $>45,000$ & 34,400 \\
\hline Vla & - & $0.05-0.2$ & 19.5 & 11 & 54 & - & 0.37 & $20,000-30,000$ & 14,100 \\
\hline VIb & - & 0.0 & 21 & 13 & 60 & - & 0.37 & $>30,000$ & 17,000 \\
\hline
\end{tabular}

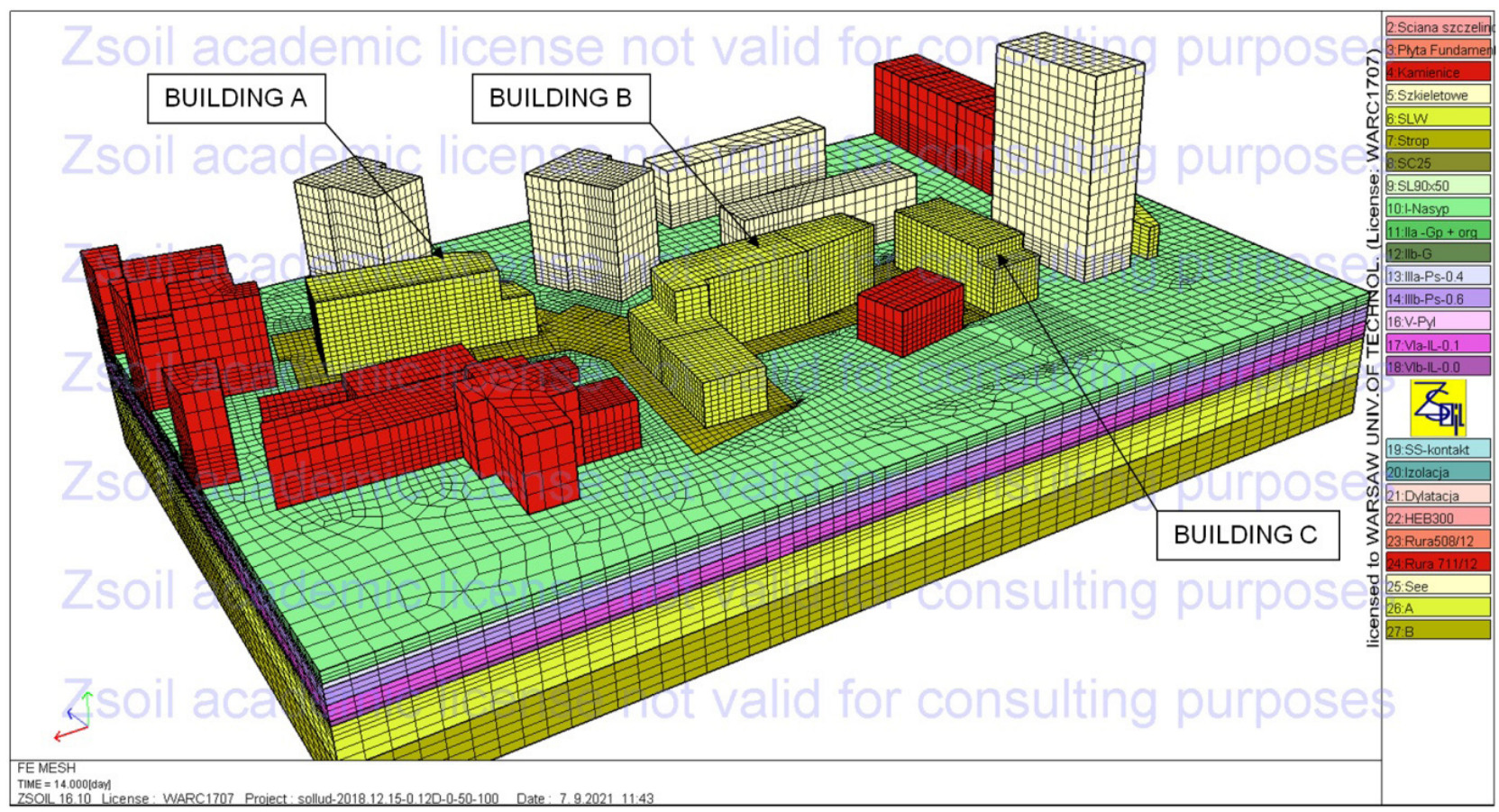

Figure 4: 3D numerical model covering the designed building complex A, B and C, neighbouring buildings and soil.

The subsoil under the buildings was modelled to a depth of $30 \mathrm{~m}$ below the ground level using the MohrCoulomb subsoil model. As characterised in [11], the model calibration consisted of increasing the value of the primary deformation modulus of the soil located at depths below the level recognised in the geotechnical documentation. The obtained displacement results for building development presented in the 3D model were compared with the displacement measurements obtained during the investment implementation. The displacement results that differed from the real displacement measurements obtained from geodetic measurements by more than double the geodetic measurement error, that is, $\pm 0.6 \mathrm{~mm}$ [11], were considered convergent. 


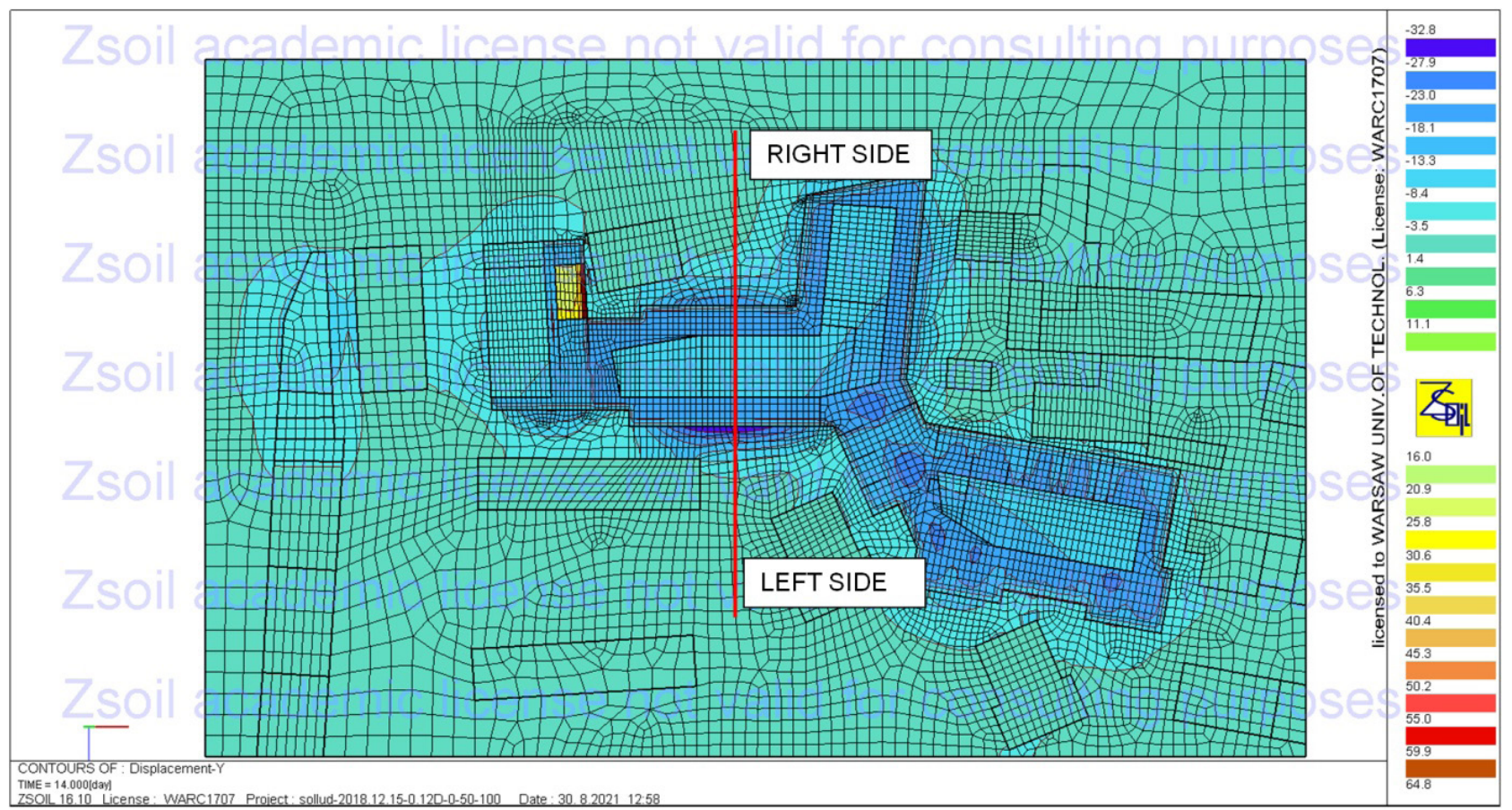

Figure 5: A numerical model section with the determination of the A-A test section placement.

\section{Results and discussion}

To analyse the impact exerted by the investment implementation on the displacement of the area surface, the A-A cross section (Fig. 5) located in the centre of a part of the $B$ building was selected from the 3D numerical model of the investment. To limit the impact of local changes that occur at the corners of the excavation support elements (straining beams), as well as to reduce the load on the ground surface with existing buildings, etc., a cross section located in the central part of the investment, outside these buildings, was selected (see Fig. 5).

Curve lines were drawn based on the vertical displacements determined from the 3D numerical model in the tested A-A cross section. These curves were intended to reflect the displacements of the area surface to the left and right from the edge of the excavation/outer surface of the slurry wall, being part of the underground level of the $\mathrm{A}, \mathrm{B}$ and $\mathrm{C}$ building complex, in the major implementation phases. Vertical displacements at a value greater than double the geodetic measurement error were assumed as occurring. The present article discusses only the drawings and diagrams that cover the phases directly related to the construction of building B, that is, phases 1, 2, 4-9 and 14 . However, while creating the numerical model, all stages of construction work in actual locations and during their occurrence were accounted for.
Phase 1 involved constructing the guide walls of the slurry walls for the excavation casing and the preliminary excavation. In this phase, no vertical displacements of the land surface were found.

Phase 2 was concerned with the creation of excavation casing slurry walls. The curved lines that define the vertical displacements of the land surface on both sides of the foundation excavation are similar in shape, that is, they form a convex trough and are similar in values. The highest vertical displacements, namely subsidence, occur directly behind the slurry walls and amount to 4.8 $\mathrm{mm}$ on the left side and $-4.9 \mathrm{~mm}$ on the right side. The disappearance of the impact zone was determined at a distance of 12 and $15 \mathrm{~m}$, respectively (Fig. 6).

Phase 4 consisted in conducting an excavation to a depth of $4.7 \mathrm{~m}$ and supporting the structure at height with pre-tensioned straining beams (Fig. 7).

Phase 5 was concerned with making the excavation to the designed depth of $4.7 \mathrm{~m}$ below the ground level (Fig. 8). The highest determined vertical displacement values, subsidence, occur in the immediate vicinity of the foundation excavation casing made of slurry walls and amount to $1.4 \mathrm{~mm}$ on both sides, respectively. The displacement curve forms a concave trough. Vertical displacements reach the value of double the geodetic measurement error on the left side, at a distance of $13 \mathrm{~m}$ from the edge of the foundation excavation. In contrast, 


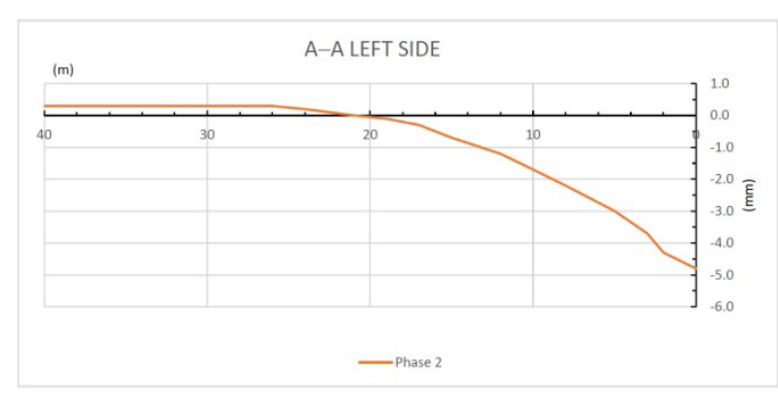

a)

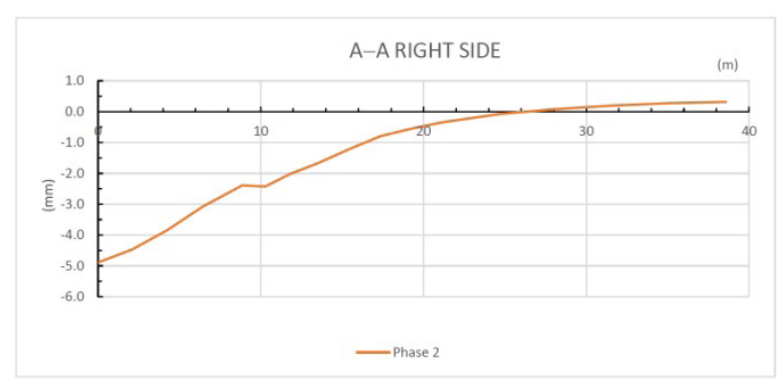

b)

Figure 6: Phase 2 of the implementation - erecting slurry walls; graph of vertical displacements of the land surface in the A-A cross section: a) on the left, b) on the right.

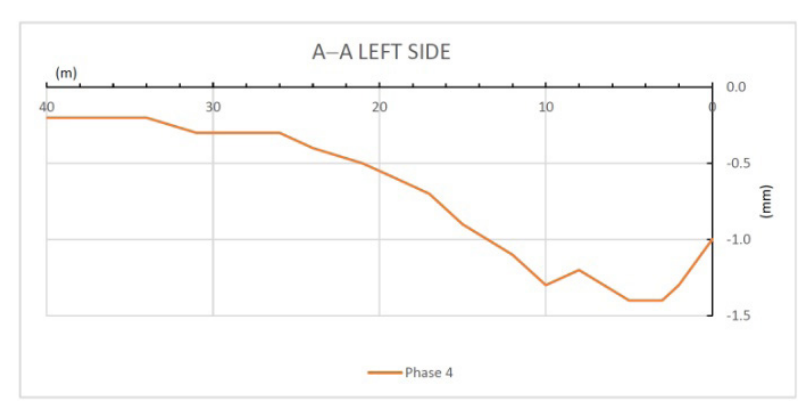

a)

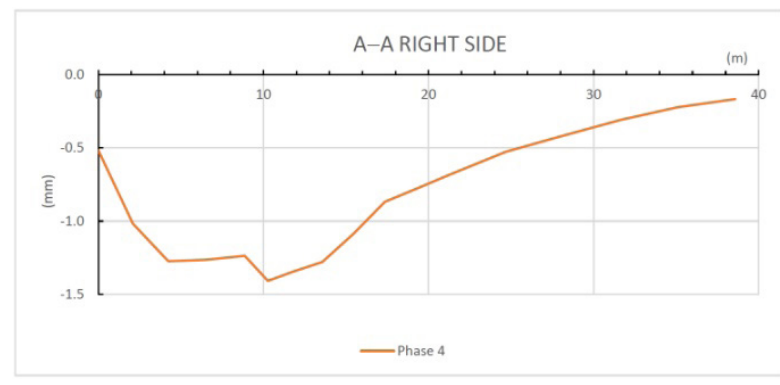

b)

Figure 7: Phase 4 of the implementation - conducting foundation excavation and supporting it with straining beams; graph of vertical displacements of the land surface in the A-A cross section: $a$ ) on the left, b) on the right.

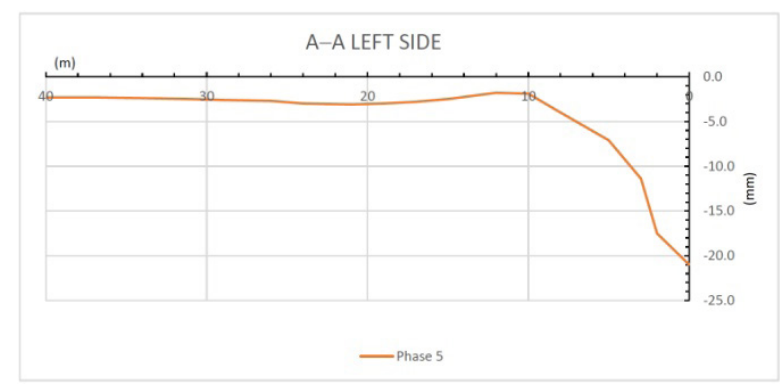

a)

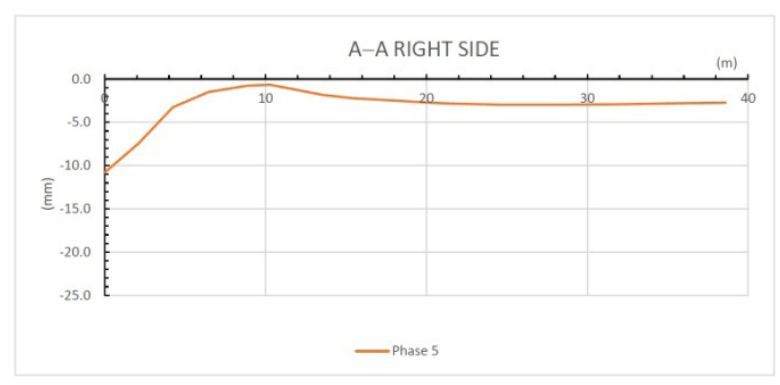

b)

Figure 8: Phase 5 of the implementation - conducting foundation excavation to the full depth; graph of vertical displacements of the land surface in the A-A cross section: a) on the left, b) on the right

on the right side, the distance stands at $14.5 \mathrm{~m}$. Further, the subsidence values increase to -2.0 and $-2.7 \mathrm{~mm}$ at the model edges, respectively.

Phase 6 involved construction of the bottom slab of building B (Fig. 9). The trough is convex in shape; the most significant vertical displacement values, that is, subsidence, occur directly behind the foundation excavation casing and amount to $-25.6 \mathrm{~mm}$ on the left side and $-15.9 \mathrm{~mm}$ on the right side. However, the disappearance of the impact zone on the left and right sides stands at a value greater than the model dimensions, that is, at over $50 \mathrm{~m}$. At a distance of $12 \mathrm{~m}$ from the edge of the excavation casing, the values of these displacements equal $-2.0 \mathrm{~mm}$ and retain relatively low values, whereas at the model's edge, namely at a distance of $50 \mathrm{~m}$, they amount to $-1.8 \mathrm{~mm}$.

The subsequent phase 7 comprised disassembly of the straining beams in the excavation part and 


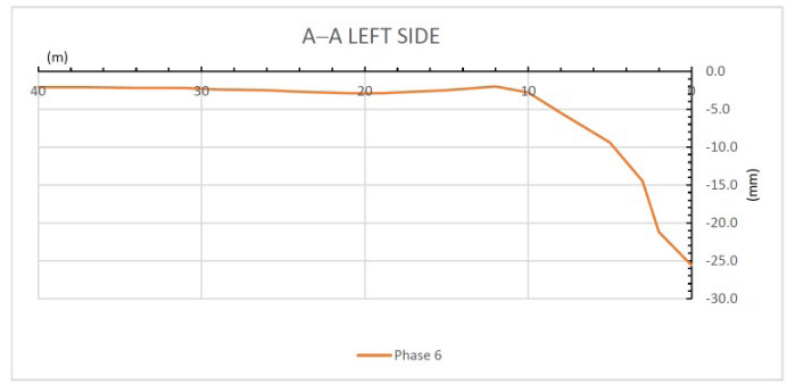

a)

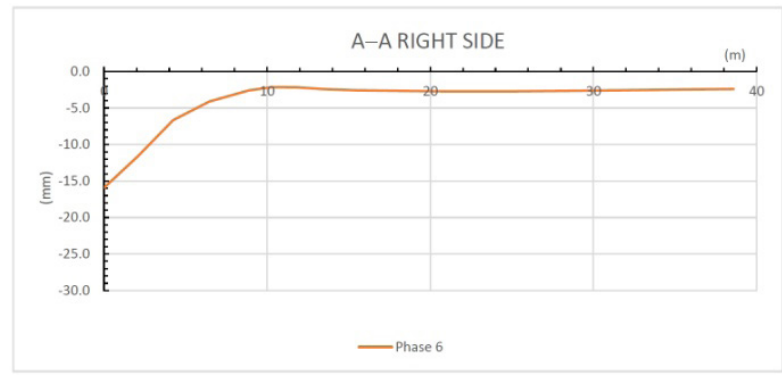

b)

Figure 9: Phase 6 of the implementation - implementation of the raft foundation; graph of vertical displacements of the land surface in the A-A cross section: a) on the left, b) on the right.

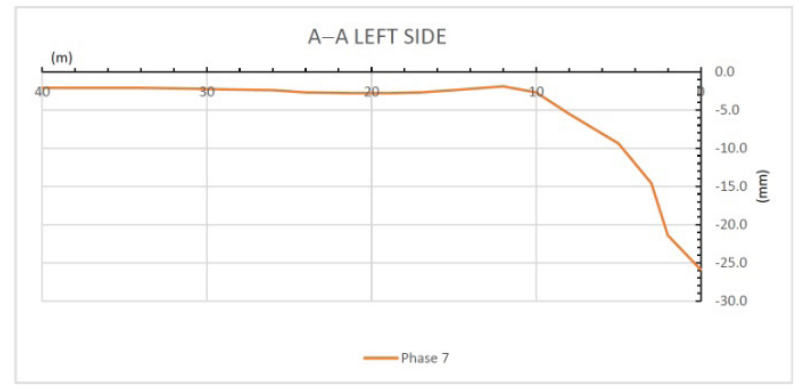

a)

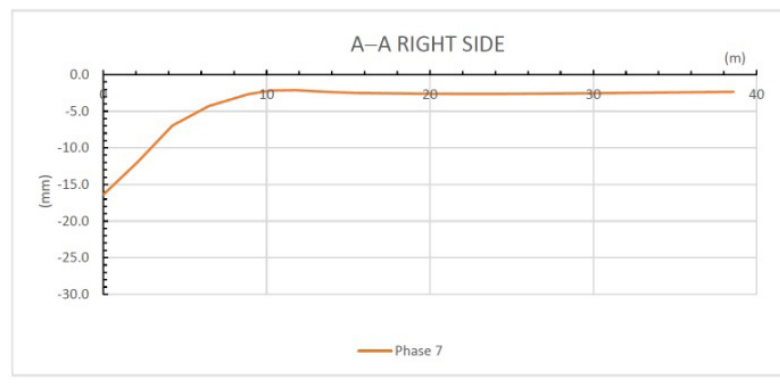

b)

Figure 10: Phase 7 of the implementation - disassembly of straining beams, followed by the construction of walls and columns in the underground part; graph of vertical displacements of the land surface in the A-A cross section: a) on the left, b) on the right

implementation of the reinforced concrete wall and column structures for the underground level (Fig. 10). The highest vertical displacement values, namely subsidence, determined from the 3D numerical model, occur directly behind the slurry walls and amount to $-25.9 \mathrm{~mm}$ on the left side and $-16.4 \mathrm{~mm}$ on the right side. In contrast, as in phase 6 , the displacement disappearance exceeds the model boundaries, that is, it occurs at $50 \mathrm{~m}$. However, already at a distance of $12 \mathrm{~m}$ from the outer edge of slurry walls, these displacement values are insignificant, as they amount to $-1.9 \mathrm{~mm}$. Moreover, they become stabilised on both sides of the model, up to the model's boundary.

Phase 8 was concerned with implementation of the ceiling above the underground level at the ground level (Fig. 11). In this case, the settlement curve creates a convex trough, and the highest values of vertical displacements occur directly behind the excavation casing and amount to $-27.8 \mathrm{~mm}$ on the left and $-18.3 \mathrm{~mm}$ on the right. At a distance of $12 \mathrm{~m}$ from the outer edge of the slurry walls on both sides, the displacement values equal -2.1 and $-2.6 \mathrm{~mm}$, respectively, and continue to stabilise at a level similar to the numerical model boundary.
Phase 9 involved construction of the above-ground part of building B (Fig. 12). The vertical displacement curve forms a convex trough. The highest values of these displacements occur directly behind the slurry walls and amount to $-27.9 \mathrm{~mm}$ on the left side and $-18.3 \mathrm{~mm}$ on the right side. At a distance of $12 \mathrm{~m}$ from these walls, the vertical displacements equal -2.1 and $-2.6 \mathrm{~mm}$, respectively. Further, they slightly decrease to the values of -1.9 and $-2.2 \mathrm{~mm}$, respectively, at the model's boundaries.

The final phase (14) comprised all loads applied to the structure and, consequently, to the subsoil, that is, loads related to the commissioning of the facility and applying the full-service load (Fig. 13). In this phase, the curve of land surface vertical displacements also formed a convex trough. The highest values of these displacements occurred directly behind the slurry walls and amounted to -32.4 on the left, $-22.7 \mathrm{~mm}$ on the right and about 2.2 $\mathrm{mm}$ at a distance of about $20 \mathrm{~m}$ on both sides. On the left, the disappearance of subsidence occurred at a distance of $29 \mathrm{~m}$, whereas on the right, towards the boundary of the numerical model, the value of vertical displacements stood at $-1.5 \mathrm{~mm}$. 


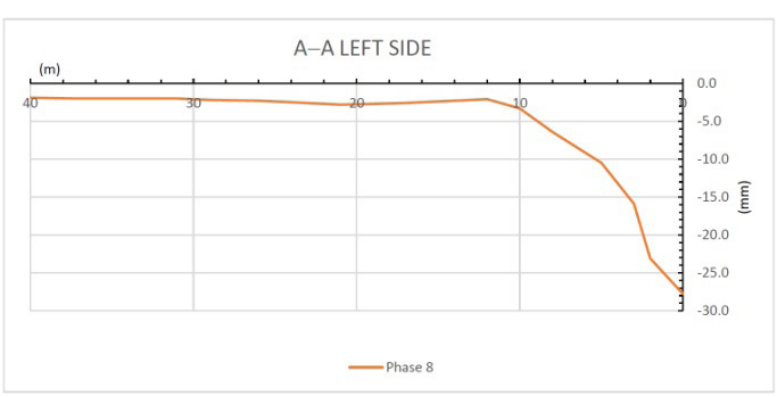

a)

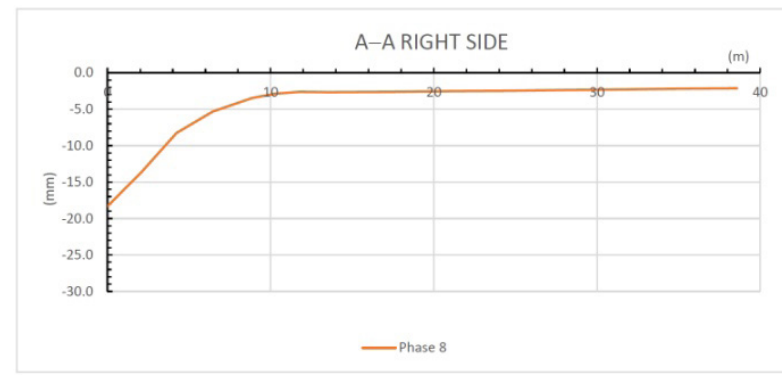

b)

Figure 11: Phase 8 of the implementation - construction of the underground part; graph of vertical displacements of the land surface in the A-A cross section: a) on the left, b) on the right.

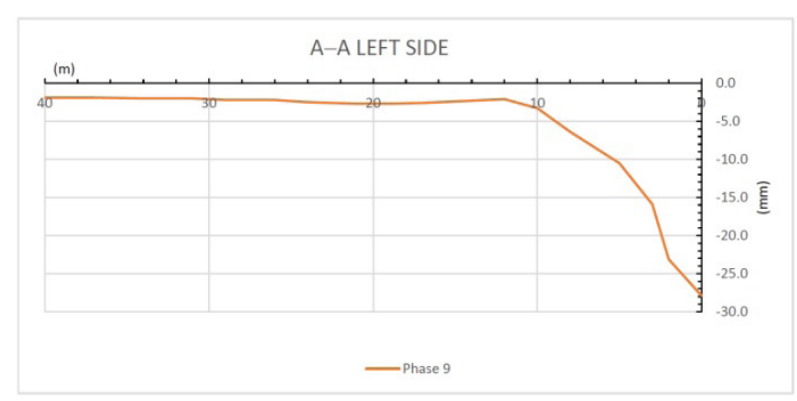

a)

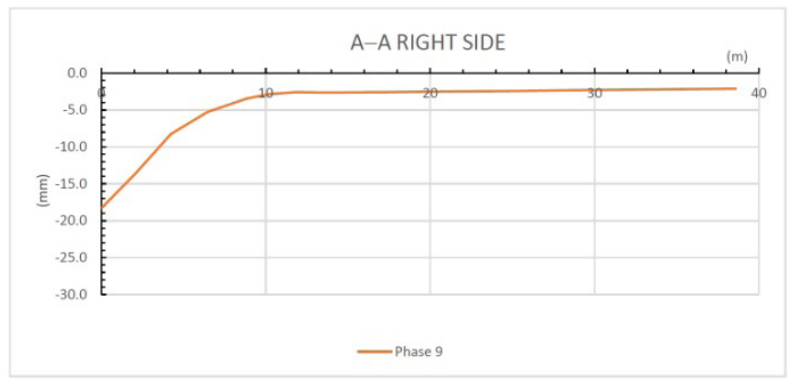

b)

Figure 12: Phase 9 of the implementation - construction of the above-ground part; graph of vertical displacements of the land surface in the A-A cross section: $a)$ on the left, b) on the right.

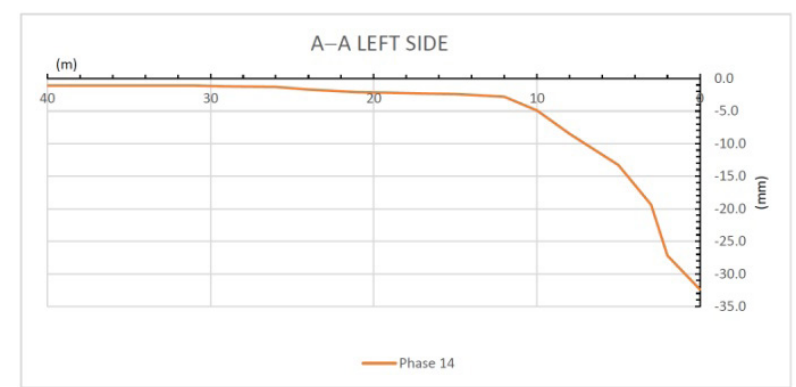

a)

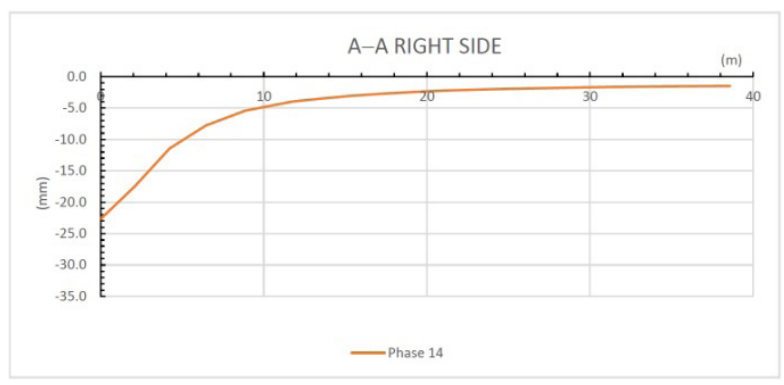

b)

Figure 13: Phase 14 of the implementation - application of the full-service load; graph of vertical displacements of the land surface in the A-A cross section: a) on the left, b) on the right.

The juxtaposition of the vertical displacement values of the land surface, obtained from the 3D numerical model in the analysed implementation phases, in the case of left side of the A-A test cross section, is presented in Table 2, whereas in the case of right side, it is shown in Table 3.

In the case in question, where the subsoil is formed mainly of sandy formations, with a foundation excavation depth at $4.7 \mathrm{~m}$, the scope of the investment's impact on the displacement of the land surface was determined, that is:
- according to [7] (see also [6]), the range of the foundation excavation (in this analysis, it was marked as phase 5), including direct impacts, equals $0.5 \mathrm{~h}$ $=2.35 \mathrm{~m}$ (see Tables 2 and 3), whereas the range of secondary impacts is $2 \mathrm{~h}=9.4 \mathrm{~m}$ (compare Tables 2 and 3);

- according to [8], the scope of the investment's impact in the phase of construction works related to erecting the underground part of the facility (in this analysis, 
Table 2: The juxtaposition of the vertical displacement values in $[\mathrm{mm}]$ of the land surface. from the 3D numerical model in the analyzed implementation phases. for the left side of the A-A test cross-section.

\begin{tabular}{|c|c|c|c|c|c|c|c|c|c|c|c|c|c|c|c|c|c|c|c|c|c|}
\hline $\begin{array}{l}\text { Distance } \\
\text { from the } \\
\text { excavation } \\
\text { (m) }\end{array}$ & 50 & 46 & 43 & 40 & 37 & 34 & 31 & 29 & 26 & 24 & 21 & 19 & 17 & 15 & 12 & 10 & 8 & 5 & 3 & 2 & 0 \\
\hline hase 1 & 0.0 & 0.0 & 0.0 & 0.0 & 0.0 & 0.0 & 0.0 & 0.0 & 0.0 & 0.0 & 0.0 & 0.0 & 0.0 & 0.0 & 0.0 & 0.0 & 0.0 & 0.0 & 0.0 & 0.0 & 0.0 \\
\hline Phase 2 & 0.2 & 0.2 & 0.3 & 0.3 & 0.3 & 0.3 & 0.3 & 0.3 & 0.3 & 0.2 & 0.0 & -0.1 & -0.3 & -0.7 & -1.2 & -1.7 & -2.2 & -3.0 & -3.7 & -4.3 & -4.8 \\
\hline hase 3 & -0.1 & -0.1 & -0.2 & -0.2 & -0.2 & -0.2 & -0.3 & -0.3 & -0.3 & -0.4 & -0.5 & -0.6 & -0.7 & -0.9 & -1.1 & -1.3 & -1.2 & -1.4 & -1.4 & -1.2 & -1.0 \\
\hline Phase 4 & -0.1 & -0.1 & -0.2 & -0.2 & -0.2 & -0.2 & -0.3 & -0.3 & -0.3 & -0.4 & -0.5 & -0.6 & -0.7 & -0.9 & -1.1 & -1.3 & -1.2 & -1.4 & -1.4 & -1.3 & -1.0 \\
\hline Phase 5 & -1.7 & -2.0 & -2.2 & -2.3 & -2.3 & -2.4 & -2.5 & -2.6 & -2.7 & -3.0 & -3.1 & -3.0 & -2.8 & -2.5 & -1.8 & -1.9 & -4.0 & -7.1 & -11.4 & -17 & -21.0 \\
\hline Phase 6 & -1.6 & -1.8 & -2.0 & -2.1 & -2.1 & -2.2 & -2.2 & -2.4 & -2.5 & -2.7 & -2.9 & -2.9 & -2.7 & -2.5 & -2.0 & -2.8 & -5.5 & -9.4 & -14 & -21. & -25.6 \\
\hline Phase 7 & -1.6 & -1.8 & -2.0 & -2.1 & -2.1 & -2.1 & -2.2 & -2.3 & -2.4 & -2.7 & -2.8 & -2.8 & -2.7 & -2.4 & -1.9 & -2.7 & -5.5 & -9.4 & -14.6 & -21 & -25.9 \\
\hline Phase 8 & -1.5 & -1.7 & -1.9 & -1.9 & -2.0 & -2.0 & -2.0 & -2.2 & -2.3 & -2.5 & -2.8 & -2.7 & -2.6 & -2.4 & -2.1 & -3.3 & -6.4 & -10.5 & -15 & -23 & $1-27.8$ \\
\hline Phase 9 & -1.5 & -1.7 & -1.9 & -1.9 & -1.9 & -2.0 & -2.0 & -2.2 & -2.2 & -2.5 & -2.7 & -2.7 & -2.6 & -2.4 & -2.1 & -3.3 & -6.4 & -10 & -1 & -2 & -27.9 \\
\hline Phase 10 & -1.4 & -1.5 & -1.7 & -1.7 & -1.7 & -1.7 & -1.8 & -1.9 & -2.0 & -2.3 & -2.6 & -2.6 & -2.5 & -2.3 & -2.1 & -3.3 & -6.5 & -10.7 & -16 & -23 & $4-28.2$ \\
\hline Phase 11 & -1.3 & -1.5 & -1.6 & -1.7 & -1.7 & -1.7 & -1.7 & -1.8 & -1.9 & -2.2 & -2.5 & -2.5 & -2.4 & -2.2 & -2.0 & -3.3 & -6.5 & -10.7 & -16 & -23 & $5-28.3$ \\
\hline Phase 12 & -1.3 & -1.4 & -1.5 & -1.6 & -1.6 & -1.6 & -1.6 & -1.7 & -1.8 & -2.1 & -2.4 & -2.4 & -2.3 & -2.1 & -2.0 & -3.4 & -6.5 & -10.8 & -16 & -2 & -28.5 \\
\hline Phase 13 & -1.2 & -1.4 & -1.5 & -1.6 & -1.5 & -1.6 & -1.6 & -1.7 & -1.8 & -2.1 & -2.4 & -2.4 & -2.3 & -2.1 & -2.0 & -3.4 & -6.6 & -10 & -1 & -2 & -28.6 \\
\hline hase 14 & -0.9 & -1.1 & -1.1 & -1.1 & -1.1 & -1.1 & -1.1 & -1.2 & -1.3 & -1.7 & -2.1 & -2.2 & -2.3 & -2.4 & -2.8 & -4.9 & -8.5 & -13.3 & -19.4 & -27.2 & $2-32.4$ \\
\hline
\end{tabular}

Table 3: The juxtaposition of the vertical displacement values in $[\mathrm{mm}]$ of the land surface. from the 3D numerical model in the analyzed implementation phases. for the right side of the A-A test cross-section.

\begin{tabular}{|c|c|c|c|c|c|c|c|c|c|c|c|c|c|c|c|c|c|}
\hline $\begin{array}{l}\text { Distance from } \\
\text { the excavation } \\
\text { (m) }\end{array}$ & 0 & 2 & 4 & 6 & 9 & 10 & 12 & 14 & 15 & 17 & 19 & 21 & 25 & 28 & 32 & 35 & 39 \\
\hline Phase 1 & 0.0 & 0.0 & 0.0 & 0.0 & 0.0 & 0.0 & 0.0 & 0.0 & 0.0 & 0.0 & 0.0 & 0.0 & 0.0 & 0.0 & 0.0 & 0.0 & 0.0 \\
\hline Phase 2 & -4.9 & -4.5 & -3.9 & -3.1 & -2.4 & -2.4 & -2.0 & -1.7 & -1.2 & -0.8 & -0.6 & -0.3 & -0.1 & 0.1 & 0.2 & 0.3 & 0.3 \\
\hline Phase 3 & -0.5 & -1.0 & -1.3 & -1.3 & -1.2 & -1.4 & -1.3 & -1.3 & -1.1 & -0.9 & -0.8 & -0.7 & -0.5 & -0.4 & -0.3 & -0.2 & -0.2 \\
\hline Phase 4 & -0.5 & -1.0 & -1.3 & -1.3 & -1.2 & -1.4 & -1.3 & -1.3 & -1.1 & -0.9 & -0.8 & -0.7 & -0.5 & -0.4 & -0.3 & -0.2 & -0.2 \\
\hline Phase 5 & -10.8 & -7.5 & -3.3 & -1.5 & -0.8 & -0.7 & -1.2 & -1.8 & -2.2 & -2.4 & -2.6 & -2.8 & -3.0 & -3.0 & -2.9 & -2.8 & -2.7 \\
\hline Phase 6 & -15.9 & -11.6 & -6.7 & -4.1 & -2.6 & -2.2 & -2.2 & -2.4 & -2.6 & -2.6 & -2.7 & -2.7 & -2.7 & -2.7 & -2.6 & -2.5 & -2.4 \\
\hline Phase 7 & -16.4 & -12.0 & -7.0 & -4.3 & -2.7 & -2.2 & -2.1 & -2.4 & -2.5 & -2.5 & -2.6 & -2.6 & -2.6 & -2.6 & -2.5 & -2.4 & -2.3 \\
\hline Phase 8 & -18.3 & -13.6 & -8.3 & -5.3 & -3.5 & -2.9 & -2.6 & -2.7 & -2.7 & -2.6 & -2.6 & -2.5 & -2.5 & -2.4 & -2.3 & -2.2 & -2.1 \\
\hline Phase 9 & -18.3 & -13.6 & -8.2 & -5.3 & -3.4 & -2.8 & -2.6 & -2.6 & -2.6 & -2.6 & -2.5 & -2.5 & -2.4 & -2.3 & -2.3 & -2.2 & -2.1 \\
\hline Phase 10 & -18.5 & -13.7 & -8.4 & -5.4 & -3.5 & -2.9 & -2.6 & -2.6 & -2.6 & -2.5 & -2.4 & -2.4 & -2.3 & -2.2 & -2.2 & -2.1 & -2.0 \\
\hline Phase 11 & -18.7 & -13.9 & -8.5 & -5.5 & -3.6 & -3.0 & -2.6 & -2.6 & -2.6 & -2.5 & -2.4 & -2.4 & -2.3 & -2.2 & -2.1 & -2.0 & -2.0 \\
\hline Phase 12 & -18.8 & -14.0 & -8.6 & -5.5 & -3.6 & -3.0 & -2.7 & -2.6 & -2.5 & -2.5 & -2.4 & -2.3 & -2.2 & -2.1 & -2.0 & -2.0 & -1.9 \\
\hline Phase 13 & -18.9 & -14.1 & -8.7 & -5.6 & -3.7 & -3.1 & -2.7 & -2.7 & -2.6 & -2.5 & -2.4 & -2.3 & -2.2 & -2.1 & -2.0 & -1.9 & -1.9 \\
\hline Phase 14 & -22.7 & -17.5 & -11.4 & -7.8 & -5.4 & -4.7 & -4.0 & -3.5 & -3.0 & -2.7 & -2.4 & -2.2 & -2.0 & -1.8 & -1.6 & -1.5 & -1.5 \\
\hline
\end{tabular}


it was marked as phase 8 ) is $1.7 \mathrm{~h}=8.0 \mathrm{~m}$ (see Tables 1 and 2);

- according to [8], the scope of the investment's impact in the phase of construction works related to erecting the above-ground part of the building, including the application of the full-service load (in this analysis, it was marked as phase 14), equals $2.8 \mathrm{~h}=13.2 \mathrm{~m}$ (see Tables 2 and 3).

The nodes of the 3D numerical model grid closest to the defined ranges are marked in colour in the tables provided.

\section{Conclusions}

The following can be concluded from the comparative analysis of the vertical displacement values of the land surface on both sides of the slurry walls being part of the foundation excavation support (see Figs 6-13, Tables 2 and 3):

- In all phases of construction works, the shape of the vertical displacement curve on both sides was consistent, that is, of convex nature (except for the convex trough, which emerged in phase 4, related to the excavation of the trench below the level of support with straining beams and the installation of straining beams).

- Until phase 4 of construction works, full compliance of the vertical displacement values on both sides of the test cross section was observed.

- In phase 5, which involved conducting the foundation excavation to its full intended depth (earlier supported by straining beams at the height in phase 4), a significant diversification occurred in terms of the highest vertical displacement values on both sides of the test cross section, that is, these displacement values were approximately twice as high on the left side as those observed on the right side.

- In subsequent phases (6-9), these displacement values further increased on both sides of the test cross section.

- The highest increases in vertical displacement values were found on both sides of the test section between phases 4 and 5, as well as between phases 9 and 14 .

The following may be concluded from a comparative analysis of the scope of impact exerted by a new investment on vertical displacements of the land surface (see Figs 6-13, Tables 2 and 3):
- The most significant impact range is related to the phase in which excavation to the full depth is made. Within this range, the largest, significant displacement values occur at a distance of $2.0 \mathrm{~h}(\mathrm{~h}$ excavation depth) from the foundation excavation edge. However, displacements of relatively small, insignificant values occur even further from the edge of the foundation excavation.

- A tendency to increase the impact range with the progress of construction works can be observed. The final phase, referred to in the article as phase 14, is associated with the highest vertical land displacement values. These land surface displacement values occurring immediately behind the excavation casing are likely to double the vertical displacements during the excavation phase (phase 5).

The construction of low-slung structures within dense urban development constitutes a complex investment project that requires numerous additional analyses and research to forecast the impact of such facilities on existing building development within the vicinity. Forecasting displacements and the range of impact of such an investment pose particular difficulties when the designed facilities come with irregular, fragmented building plans. According to the authors, using empirical formulas to determine these interactions may provide a basis for estimating the impact range in the case of linear objects. However, due to the overlapping of many interactions and the effects of constructions with irregular plans, it seems reasonable in their case to supplement the analysis with the 3D numerical modelling proposed in the present article. This type of modelling may more accurately reflect the actual location of the neighbouring building development and the resulting load on the subsoil, as well as the loads that emerge under the schedule of the construction work execution phase.

\section{References}

[1] Clough, G.W., O’Rourke, T.D. (1998). Construction induced movements of in-situ walls. Proceedings of Conference Design and Performance of Earth Retaining Structures, New York.

[2] Symons, I.F., Carder, D.R. (1992). Field measurements on embedded retaining walls. Geotechnique, 30(1), 117-126.

[3] Breymann, H., Freiseder, M., Schweiger, H. F. (1997). Deep excavations in soft ground, in-situ measurements and numerical predictions. XIV International Conference of Soil Mechanics and Foundations Engineering. Hamburg.

[4] Simpson, B., Calabresi, G., Sommer, H., Wallays, M. (1979) Design parameters for stiff clays. VII ECSMFE, Brighton. 
[5] Smoltczyk, U. (Eds.) (2002, 2003). Geotechnical Engineering Handbook. Vol. 1 - Fundamentals (2002); Vol. 2 - Procedures (2003); Vol. 3 - Elements and Structures (2003). Ernst \& Sohn, A Wiley Company.

[6] Michalak, H, Pęski, S, Pyrak, S, Szulborski, K. (1998). On the impact of deep excavations on neighbouring buildings. Inżynieria i Budownictwo, 1/1998, 12-15.

[7] Wysokiński, L, Kotlicki, W. (2002). Protection of buildings adjacent to deep excavations. Recommendation 376. Building Research Institute Warsaw.

[8] Michalak, H. (2006). Structural and spatial development of underground garages in highly urbanized areas. Architecture series - issue 2, (pp. 25-51). Publishing House of Warsaw University of Technology.

[9] Michalak, H. (2009). Selected problems of designing and constructing underground garages in intensively urbanized areas. In C. Madryas, B. Przybyła \& A. Szot (Eds.), Underground Infrastructure of Urban Areas (pp. 193-201). CRC Press / Balkema, Taylor \& Francis Group, A Balkema Book.

[10] Obrzud, R, Podleś, K. (2016). Examples of large-scale simulations of soil-structure interaction with ZSoil. Rossolis Editions \& Zace Services Ltd.

[11] Michalak, H., Przybysz, P. (2021) Subsoil movements forecasting using $3 \mathrm{~d}$ numerical modeling. Archives of Civil Engineering, 67(1), 367-385, https://doi.org/10.24425/ ace.2021.136478.

[12] Burland, J.B., Simpson, B., St. John, H.D. (1979). Movements around excavations in London Clay. 7th European Conference on Soil Mechanics and Foundation Engineering, London.

[13] Kłosiński, B. (2002). Projektowanie obudów głębokich wykopów. Głębokie wykopy na terenach wielkomiejskich. IDiM PW \& IBDiM, Warsaw.

[14] Siemińska-Lewandowska, A. (2010). Gtębokie wykopy projektowanie i wykonawstwo. Wydawnictwa Komunikacji i tączności WKt.

[15] Staszewska K., Cudny, M. (2020). Modelling the timedependent behaviour of soft soils. Studia Geotechnica et Mechanica, 42(2), 97-110, https://doi.org/10.2478/sgem2019-0034.

[16] Bałachowski, L. (2014). Deep compaction control of sandy soils. Studia Geotechnica et Mechanica, 36(2), 2014, https:// doi.org/10.2478/sgem-2014-0014.

[17] Górska, K., Wyjadłowski, M. (2012). Analysis of displacement of excavation based on inclinometer measurements. Studia Geotechnica et Mechanica, 34(4), https://doi.org/10.5277/ sgm041201.

[18] Kowalska M. (2012). Influence of loading history and boundary conditions on parameters of soil constitutive models. Studia Geotechnica et Mechanica, 34(1), https://doi.org/10.1515/ sgem-2017-0020.

[19] Truty A. (2018). On consistent nonlinear analysis of soilstructure interaction problems. Studia Geotechnica et Mechanica, 40(2), 86-95, https://doi.org/10.2478/sgem-20180019.

[20] Bobylev, N. (2015). Underground space as an urban indicator: Measuring use of subsurface. Tunnlling and Underground Space Technology, 55, 40-51, https://doi.org/10.1016/j. tust.2015.10.024.

[21] Jiang, S., Wang, Y. (2019). Long-Term Ground Settlements over Mined-Out Region Induced by Railway Construction and
Operation. Sustainability, 11(3), 875, https://doi.org/10.3390/ su11030875.

[22] Agnella, D., Giannotti, W.J., Rosatti Filho, M.A.. Oliveira Pires, T. (2018). PAT TBM improving - A case study to Metro Sao Paulo. In A. Negro, M.O. Jr. Cecílio, (Eds.) Geotechnical Aspects of Underground Construction in Soft Ground, Proceedings of the 9th International Symposium on Geotechnical Aspects of Underground Construction in Soft Ground, Sao Paulo, Brazil, 4-6 April 2017. Taylor \& Francis Group, London.

[23] Ramadan, E.H., Ramadan, M., Khashila, M.M., Kenawi, M.A. (2013). Analysis of Piles Supporting Excavation Adjacent to Existing Buildings. 18th International Conference on Soil Mechanics and Geotechnical Engineering, Paris, France, 2-6 September 2013; pp. 2835-2838. Available online: https:// www.researchgate.net/publication/272507779 (accessed on 2 December 2020).

[24] Lei, G.H., Sun, H.S., Ng, C.W.W. (2014). An approximate analytical solution for calculating ground surface settlements due to diaphragm walling. Computers and Geotechnics, 61, 108-115, https://doi.org/10.1016/j.compgeo.2014.05.002.

[25] Hu, B., Wang, C. (2019). Ground surface settlement analysis of shield tunneling under spatial variability of multiple geotechnical parameters. Heliyon, 5, e02495, https://doi. org/10.1016/j.heliyon.2019.e02495.

[26] Lu, H., Shi, J., Wang, Y., Wang, R. (2019). Centrifuge modeling of tunneling-induced ground surface settlement in sand. Underground Space, 4(4), 302-309, https://doi.org/10.1016/j. undsp.2019.03.007.

[27] Korff, M., Mair, R.J. (2013). Ground displacements related to deep excavation in Amsterdam. 18th International Conference on Soil Mechanics and Geotechnical Engineering, Paris, France, 2-6 September 2013; pp. 2779-2782. Available online: http:// www.cfms-sols.org/sites/default/files/Actes/2779-2782.pdf (accessed on 26 February 2021).

[28] Korff, M. (2018) Case Studies and Monitoring of Deep Excavations. In A. Negro, M.O. Jr. Cecílio, (Eds.) Geotechnical Aspects of Underground Construction in Soft Ground, Proceedings of the 9th International Symposium on Geotechnical Aspects of Underground Construction in Soft Ground, Sao Paulo, Brazil, 4-6 April 2017. Taylor \& Francis Group, London. Available online: http://resolver.tudelft.nl/ uuid:fe0af6c8-5588-4a06-8e8b-1c75af49ef28 (accessed on 2 December 2020)

[29] Masuda, T. (1996). A study of empirical correlation for lateral deflections of diaphragm walls in deep excavations. International Symposium on Geotechnical Aspects of Underground Construction in Soft Ground, Balkema, Rotterdam, 1996, 19-21 July; pp. 167-172; Available online: https://www.issmge.org/uploads/ publications/6/8/1996_024.pdf (accessed on 2 December 2020).

\section{Design documentation used}

[30] Domurad, J., Kościuch, P., Domurad, J., Karwan, R. (2016). Projekt konstrukcyjny ścian szczelinowych, tymczasowego rozparcia i pali Solec - Ludna - Wilanowska, Warsaw, Poland. 
[31] Korczak, P. (2016-2018). Dokumentacja pomiarów geodezyjnych Solec/Ludna/Wilanowska. Pomiary przemieszczeń, Warsaw, Poland.

[32] Kuryłowicz, S., Kuryłowicz, E., Gientka, T., Krześniak, M., Miklaszewska, K., Pianko, M., Tęskny, M., Kuczyński, P. (20102017). Projekt architektoniczny zabudowy mieszkaniowej z garażem podziemnymi i usługami ul. Solec/Ludna/Wilanowska, Warsaw, Poland.

[33] Szulborski, K., Majewska, A., Michalak, H., Paziewski, T., Pęski, S., Przybysz, P. Pyrak, S. (2010). Ekspertyzy techniczne sasiedniej zabudowy i ocena wptywu realizacji zespołu mieszkaniowego SBM TORWAR przy ul. Solec/Ludna/ Wilanowska w Warszawie, Warsaw, Poland.

[34] Wolski, W. with the team (2009) Dokumentacja geologicznoinżynierska ustalająca geotechniczne warunki posadowienia dla potrzeb projektu inwestycji zlokalizowanej w rejonie ul. Ludnej i ul. Solec w Warszawie, Warsaw, Poland. 